\title{
Dose Dependent Morphological Effects of Alpha Lipoic Acid on Vasospastic Femoral Artery in Rats
}

\author{
Suçanlarda Alfa Lipoik Asidin Vazospastik Femoral Arterde Doza Bağımlı \\ Morfolojik Etkileri
}

Tugrul TON ${ }^{1}$, Aysegul OZDEMIR OVALIOGLU ${ }^{1}$, Ozlem TON ${ }^{2}$, Turgay BILGE ${ }^{1}$, Talat KIRIS ${ }^{3}$

${ }^{1}$ Haseki Education and Research Hospital, Department of Neurosurgery, Istanbul, Turkey

${ }^{2}$ Sisli Etfal Education and Research Hospital, Department of Pathology, Istanbul, Turkey

Istanbul University, Istanbul Faculty of Medicine, Department of Neurosurgery, Istanbul, Turkey

Correspondence address: Ayşegul OZDEMIR OVALIOGLU / E-mail: draysegulozdemir@yahoo.com

\begin{abstract}
AIM: The dose dependent effects of alpha lipoic acid ( $a-L A)$ were investigated morphologically on rat vasospasm model.

MATERIAL and METHODS: 32 rats were divided into four groups: group I=control; group II=vasospasm; group III=vasospasm +low dose (20 $\mathrm{mg} / \mathrm{kg})$ intraperitoneal a-LA administered; and group IV=vasospasm +high dose $(100 \mathrm{mg} / \mathrm{kg})$ intraperitoneal a-LA administered. Histological and morphometric examinations were carried out for each groups under light microscope.

RESULTS: The mean vascular wall thickness displayed significant increase in group II and III compared with group I ( $<<.05)$. Statistical comparison of group II and IV, regarding vascular wall thickness showed a significant decrease in group IV, and regarding vascular lumen area showed a significant increase in group IV $(p<.05)$.

CONCLUSION: It is demonstrated a-LA reduces the effects of vasospasm in high dose treatment group by decreasing the wall thickness and increasing the lumen surface area. The present study suggests that adequate dose of a-LA is a potential therapeutic agent in experimental vasospasm model.
\end{abstract}

KEYWORDS: Alpha lipoic acid, Cerebral vasospasm, Rat femoral artery, Subarachnoid hemorrhage

öz

AMAÇ: Alfa lipoik asidin (a-LA) doza bağımlı etkileri bir sıçan vazospazm modelinde morfolojik olarak araştırılmıştır.

YÖNTEM ve GEREÇLER: 32 sıçan dört gruba bölünmüştür: grup I = kontrol; grup II = vazospazm; grup III = vazospazm + düşük doz (20 mg/ kg) intraperitoneal a-LA uygulaması ve grup IV = vazospazm + yüksek doz $(100 \mathrm{mg} / \mathrm{kg})$ intraperitoneal a-LA uygulaması. Her grup için ışık mikroskopu altında histolojik ve morfometrik incelemeler yapılmıştır.

BULGULAR: Ana vasküler duvar kalınlığı grup II ve III'te grup I ile karşılaştırıldığında önemli bir artış göstermiştir $(p<0,05)$. Grup II ve IV'ün istatistiksel olarak karşılaştırılması vasküler duvar kalınlığı açısından grup IV'te önemli bir azalma ve vasküler lümen açısından yine grup IV'te önemli bir artış göstermiştir $(p<0,05)$.

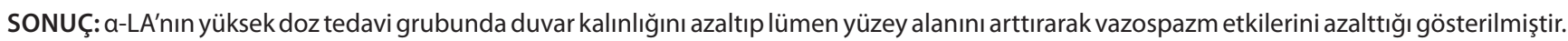
Mevcut çalışma yeterli dozda a-LA'nın deneysel bir vazospazm modelinde potansiyel bir terapötik ajan olduğunu düşündürmektedir.

ANAHTAR SÖZCÜKLER: Alfa lipoik asit, Serebral vazospazm, Sıçan femoral arteri, Subaraknoid kanama

\section{INTRODUCTION}

Cerebral vasospasm (CV) is a significant source of morbidity and mortality in patients with subarachnoid hemorrhage (SAH). Despite of many articles published each year on the topic of $\mathrm{CV}$, the pathophysiology has not been clearly demonstrated and there is still no efficient treatment against this delayed effect of SAH. The exact mechanisms by which SAH induces arterial vasospasm remains to be a subject of considerable research and debate.

Alpha lipoic acid (a-LA), an organo-sulfur compound derived from octanoic acid, have the characteristics of strong natural antioxidant, penetrating blood brain barrier, no serious side effects, soluble in both fat and water, anti-inflammatory and metal chelating effects. $a-L A$ is essential for life and aerobic metabolism. a-LA has been used nutritionally and clinically since the 1950s for a number of diseases and conditions. One of the most studied clinical uses of $a-L A$ is the treatment of diabetes and diabetic neuropathy (15). Neuroprotective effect of a-LA has been shown in several studies on neurological diseases, such as traumatic brain injury (18), cerebral ischemia (17), seizures (6), autoimmune encephalomyelitis (10), and Alzheimer (1) and Parkinson diseases (3). The aim of the current study was to determine dose dependent effects of 
a-LA on vasospastic femoral artery in a rat model by analysing the histological and morphometric changes.

\section{MATERIAL and METHODS}

The present experimental study was conducted under the approval of the ethics committee institute for experimental medical research, (DETAE), Istanbul Faculty of Medicine, Istanbul University. The surgical part of the study was performed in the animal laboratory of the same institute. Histopathological and morphometric analysis were carried out in the laboratory of pathology department of Sisli Etfal Education and Research Hospital. Thirty two male SpragueDawley rats weighing 210-260 gr, microsurgical tools and surgical microscope were used in our study. The rat femoral artery vasospasm model of Okada et al. was preferred as vasospasm model (16).

Thirty two rats were randomly separated into four groups: group I ( $n=8)$, control group; group II $(n=8)$, vasospasm group; group III ( $n=8)$, vasospasm + intraperitoneal low dose $(20 \mathrm{mg} /$ $\mathrm{kg}$ ) a-LA treatment group; and group IV $(\mathrm{n}=8)$, vasospasm + intraperitoneal high dose $(100 \mathrm{mg} / \mathrm{kg}$ ) a-LA treatment group. All rats were exposed to percutaneous intraperitoneal $60 \mathrm{mg} / \mathrm{kg}$ ketamine $\mathrm{HCl}$ (Ketalar vial, Eczacıbaşı, Turkey) and $10 \mathrm{mg} / \mathrm{kg}$ xylazine (Rompun 2\%, Bayer, Turkey) for sedation and they were located on the wood block in supine position and allowed to breathe spontaneously. While performing sterile microsurgical technique, the femoral vascular bundle was exposed in the inguinal region by a longitudinal $2 \mathrm{~cm}$ skin incision under surgical microscope. The femoral artery was dissected meticulously from the femoral vein and nerve without being traumatized. 1-1,5 cm of a silastic sheath was wrapped around the femoral artery and sutured. Autologous fresh tail blood of the subjects was used as whole blood. In groups II, III and IV, 0,1 $\mathrm{ml}$ fresh tail blood was applied directly to the femoral artery in the silastic sheath for generation of a peripheral vasospasm model. Control group I femoral arteries were covered only with a silastic sheath. As the rats in groups I and II were delivered intraperitoneal 0,3 $\mathrm{ml} /$ day 0,9\% saline, the rats in group III were subjected to intraperitoneal $20 \mathrm{mg} /$ kg/day a-LA (Thioctacid ', Gen ilaç, Ankara, Turkey) and the rats in group IV were subjected to intraperitoneal $100 \mathrm{mg} / \mathrm{kg} /$ day a-LA for seven days. Rats were fed with mouse diet and kept at room temperature in separate cages for seven days. No subject required exclusion due to mortality or disease.

On day 7, rats were reanesthetized intraperitoneally with 50 $\mathrm{mg} / \mathrm{kg}$ ketamine and $10 \mathrm{mg} / \mathrm{kg}$ xylazine. The silastic sheath wrapped around the femoral artery was accessed by opening the earlier surgical incisions and the femoral artery was exposed from the silastic sheath. Meanwhile, the surface of the sternum was shaved. Following sterilization with povidine iodine, the sternum was cut from the attachment points with the ribs and the thorax was explored. By opening the pericardium, puncture was applied to the left ventricle with a green-tipped injection needle. A serum set was fixated onto the end of this catheter, perfusion was performed at a standard height of $100 \mathrm{~cm}$ from the chest and $300 \mathrm{ml}$ of $0.9 \% \mathrm{NaCl}$ solution was delivered to the left ventricle. A mixture of 100 $\mathrm{ml} 0.03 \mathrm{M}$ phosphate buffer, $200 \mathrm{ml}$ of $4 \%$ paraformaldehyde and $1 \%$ glutaraldehyde solution was delivered to the left ventricle. The administration of the solution was continued until spotting a clear fluid coming out of the right atrium. After perfusion fixation, right femoral artery was incised 1-1.5 cm long and removed for histopathological and morphometric analysis in all groups. After this procedure, the rats were killed by delivering a megadose of intraperitoneal ketamine. Femoral artery specimens kept in 10\% formaldehyde were put into the tissue processor and treated with formalin for fixation purposes. Following dehydration with graded alcohol, it was processed in xylene stage and embedded in paraffin. Frozen paraffin sections of $5 \mu$ thickness were obtained and deparaffinized for $1 \mathrm{~h}$ in the incubator. Deparaffinization was continued with xylene (three times). The sections were treated with graded alcohol, rehydrated, washed with water, and stained with hematoxylin eosin. The preparations were examined under $\times 100, \times 200$, and $\times 400$ magnifications with an Olympus (Olympus BX7, Japan) microscope and their photographs were taken for morphometric analysis. Vascular wall thicknesses and lumen cross sectional areas were measured as unit values by the micrometer. Measurements were carried out on the photographs taken under $\times 40$ magnification. The specimens were compared in terms of vascular lumen area and wall thickness in the morphometric analysis.

Vascular wall thicknesses and vascular lumen areas were morphometrically measured in all groups and evaluated statistically by SPSS (v. 15.0) and Kruskal-Wallis one way analysis for variance. A value of $p<.05$ was recognized as statistically significant.

\section{RESULTS}

\section{Histological Changes}

Femoral artery cross sections were examined under light microscope in all the four groups. Arterial wall in group I had thin and normal smooth endothelium, thin and unfolded internal elastic lamina, concentrically oriented smooth muscle cells, and the lumen was clearly observed (Figure 1). Arteries in vasospasm alone group II, under light microscopy, had significant narrowing in the lumen width, apparent thickening in the vascular wall, disruption of endothelial integrity, folding in the internal elastic lamina, and vacuolizations in the muscle layer (Figure 2).

In $20 \mathrm{mg} / \mathrm{kg}$ a-LA administered group III, light microscopy found out that femoral artery wall had a thinner and smoother endothelium than the group II, mildly folded internal elastic lamina, and concentric smooth muscle cells (Figure 3).

In $100 \mathrm{mg} / \mathrm{kg}$ a-LA administered group IV, light microscopic examination of the femoral artery showed vascular wall had a thin and smooth endothelium, very thin and mildly folded internal elastic lamina, and concentric smooth muscle cells. This appearance was similar to the control group I (Figure 4). 


\section{Morphometric Analysis}

Comparisons across rat groups were performed after completing of measurement of the femoral artery wall thicknesses and lumen areas (Table I, II; Figure 5, 6). The lumen cross sectional area and wall thickness of all the femoral arteries were summarized as the mean and standard deviation values. Vasospasm alone group (group II) demonstrated the higher vessel wall thickness and the lower lumen area as compared with group I ( $p<.05$; Table I, II). This was indicative of the development of a considerable vasospasm following delivery of blood to the periarterial areas compared with the control group.

Group IV showed a significant decrease in terms of mean vascular wall thickness and increase in lumen area compared with group II ( $p<.05$; Table I, II). No significant difference was found between the mean vascular wall thickness and lumen area of groups IV and I ( $p>05$ ), while group IV showed larger

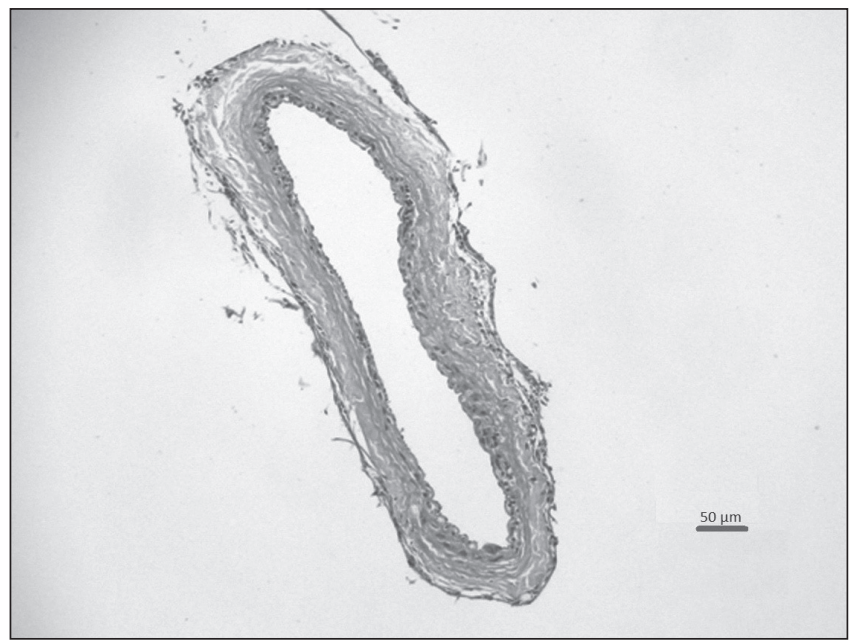

Figure 1: Light microscopic view of the control group (Group I; $H \& E, x 200)$.

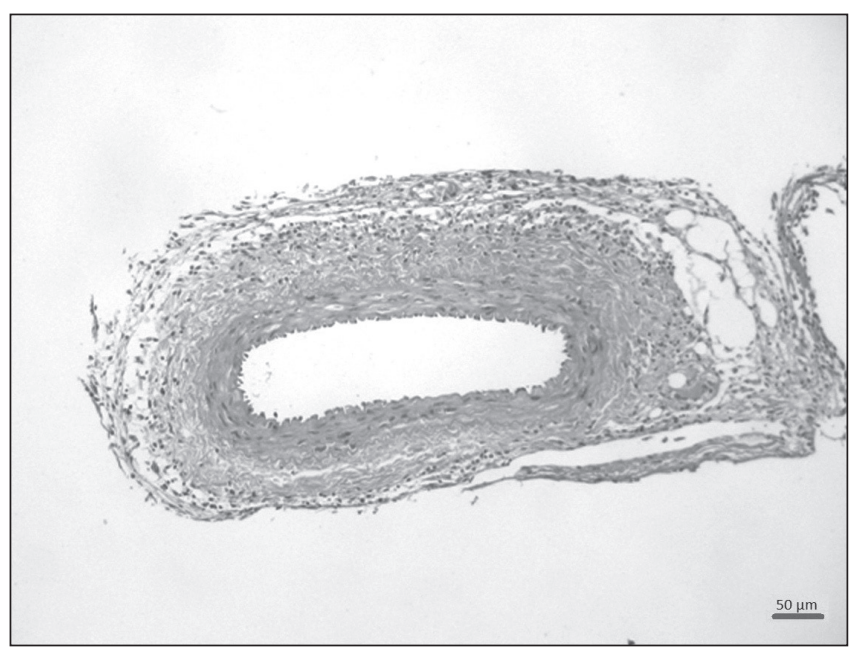

Figure 3: Light microscopic view of low dose $20 \mathrm{mg} / \mathrm{kg}$ a-LA administered group (Group III; H\&E, x200). lumen area than group I in measurements but it was not significant statistically. The statistical comparison of the mean vascular wall thickness between group III (low dose a-LA) and IV (high dose $a-L A$ ) displayed no significant difference ( $p>05$ ), whereas comparison of vascular lumen areas showed a significant increase in group IV ( $p<.05$; Table III).

We also measured blood glucose levels of the subjects before starting the study and ending for histological analysis because of that a-LA has been used in the treatment of diabetes mellitus. The comparison of first and last blood glucose levels of each groups showed that the decrease of last blood glucose levels of groups 3 and 4 ( $a$-LA administered) was statistically significant ( $p<.05$; Table IV). The first and last blood glucose levels of groups 1 and 2 (control and vasospasm groups) was found insignificantly different ( $p>05$; Table IV). During the study, we were able to know that none of the subjects showed hypoglycemia.

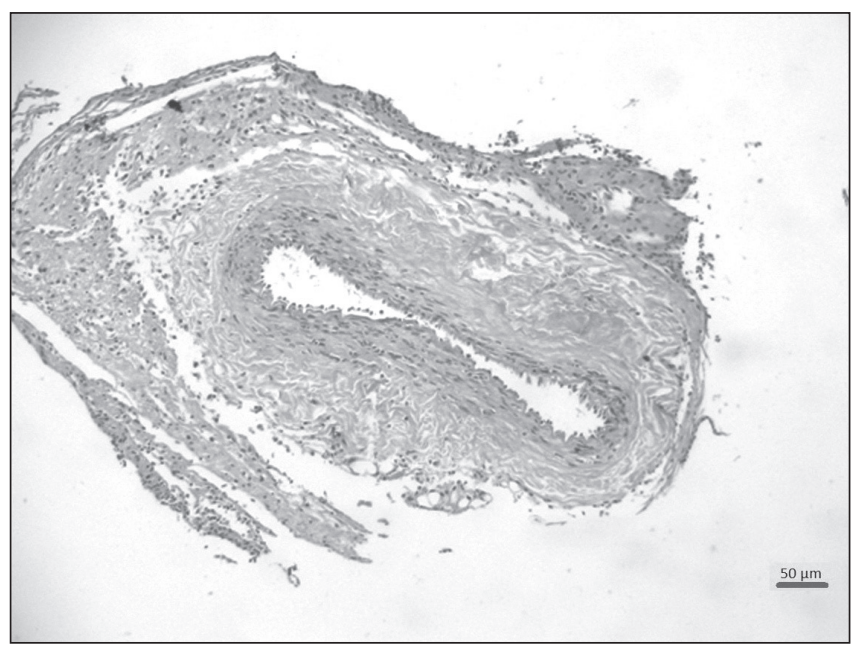

Figure 2: Light microscopic view of the vasospasm group (Group II; H\&E, x200).

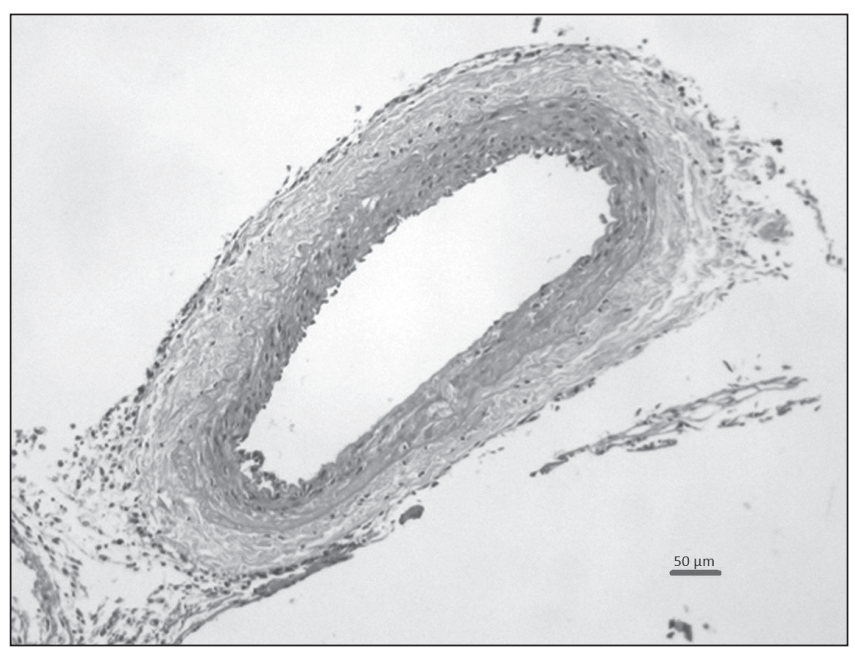

Figure 4: Light microscopic view of high dose $100 \mathrm{mg} / \mathrm{kg}$ a-LA administered group (Group IV; H\&E, x200). 


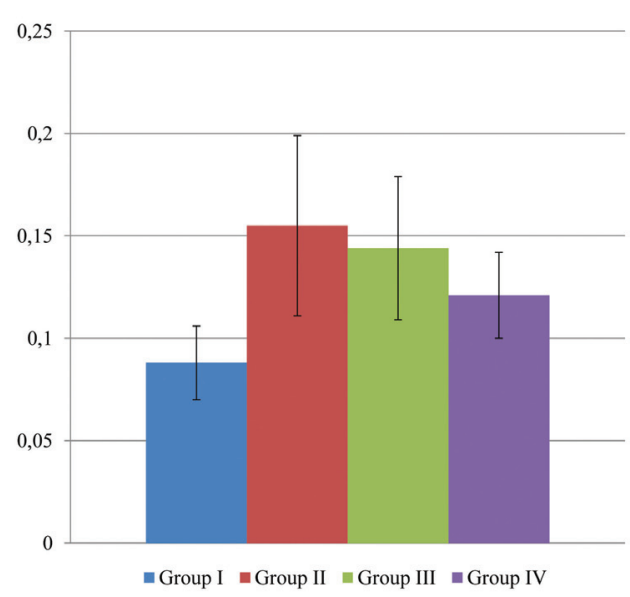

Figure 5: Comparison of mean vessel wall thickness of the four groups.

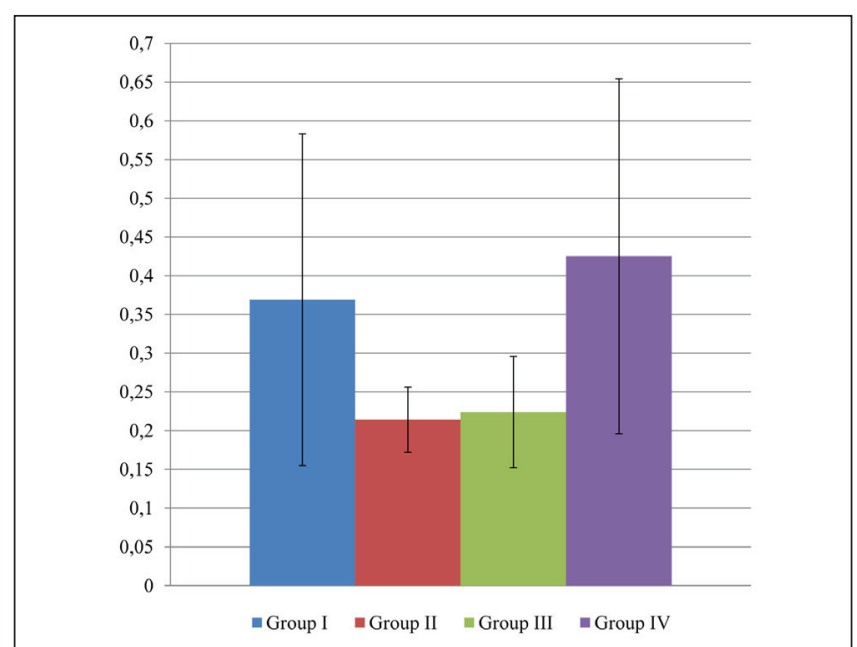

Figure 6: Comparison of vascular lumen area of the four groups.

Table I: Statistical Analysis of the Mean Vessel Wall Thickness Values of the Four Groups \pm Standard Deviation (mm)

\begin{tabular}{|l|c|c|c|c|c|c|c|c|}
\hline & \multicolumn{2}{|c|}{ Group I } & \multicolumn{2}{c|}{ Group II } & \multicolumn{2}{c|}{ Group III } & \multicolumn{2}{c|}{ Group IV } \\
\cline { 2 - 9 } & Mean & \pm Sd & Mean & \pm Sd & Mean & \pm Sd & Mean & \pm Sd \\
\hline Wall thickness & 0,088 & 0,018 & 0,155 & 0,044 & 0,144 & 0,035 & 0,121 & 0,021 \\
\hline
\end{tabular}
${ }^{*} p<.05$

Table II: Statistical Analysis the Mean Vascular Lumen Area Values of the Four Groups \pm Standard Deviation $\left(\mathrm{mm}^{2}\right)$

\begin{tabular}{|l|c|c|c|c|c|c|c|c|}
\hline & \multicolumn{2}{|c|}{ 1. Grup } & \multicolumn{2}{c|}{ 2. Grup } & \multicolumn{2}{c|}{ 3. Grup } & 4. Grup \\
\cline { 2 - 9 } & Mean & \pm Sd & Mean & \pm Sd & Mean & \pm Sd & Mean & \pm Sd \\
\hline \multirow{2}{*}{ Lumen area } & 0,369 & 0,214 & 0,214 & 0,042 & 0,224 & 0,072 & 0,425 & 0,229 \\
\hline
\end{tabular}

${ }^{*} p<.05$

Table III: Statistical Analysis of the Mean Vessel Wall Thickness Values of the Groups III and IV \pm Standard Deviation (mm)

\begin{tabular}{|l|c|c|c|c|}
\hline \multirow{2}{*}{} & \multicolumn{2}{|c|}{ Group III } & \multicolumn{2}{c|}{ Group IV } \\
\cline { 2 - 5 } & Mean & \pm Sd & Mean & \pm Sd \\
\hline Wall thickness & 0,144 & 0,035 & 0,121 & 0,021 \\
\hline
\end{tabular}

${ }^{*} p>05$

Table IV: Statistical Analysis of the Mean First and Last Blood Glucose Levels (BGL) of the Four Groups \pm Standart Deviation (mg/dL)

\begin{tabular}{|c|c|c|c|c|c|}
\hline & \multicolumn{2}{|c|}{ First BGL } & \multicolumn{2}{|c|}{ Last BGL } & \multirow{2}{*}{$\mathrm{P}$} \\
\hline & Mean & $\pm S d$ & Mean & $\pm S d$ & \\
\hline Group I & 296,88 & 51,37 & 286,25 & 41,55 & .080 \\
\hline Group II & 266,63 & 43,76 & 215,75 & 29,41 & .068 \\
\hline Group III & 268,38 & 32,01 & 210,63 & 40,30 & $.012 *$ \\
\hline Gropu IV & 297,00 & 53,05 & 200,88 & 26,33 & $.012 *$ \\
\hline
\end{tabular}

${ }^{*} p<.05$ 


\section{DISCUSSION}

Pathophysiology of cerebral vasospasm is complex and multifactorial. The oxidative stress is one of the factors which provoke vasospasm after SAH $(11,12)$. It is believed that oxidative stress stimulates hypertrophy and proliferation of smooth muscle cells and causes the increase of endothelial apoptosis. These changes are related to the contractile response of the vessels. There is a correlation between the development of cerebral vasospasm and increased superoxide anion levels in cerebrospinal fluid after SAH (2). Various studies of vasospasm performed on several animals e.g. rats, pigs, cats, dogs, and rabbits have been reported. It is found that ferrous chelators, eg. Ebselen, Tililazad, Nicaraven and inhibitors of the enzymes producing free radicals, reduce the vasospasm on animal SAH models $(7,8,9,14,19)$.

We analysed the morphological evaluation of vasospasm by using femoral artery vasospasm model of Okada et al. (16). Although the response of cerebral arteries against injury is not the same as systemic arteries, clinical and experimental knowledge suggests that vasospasm is related directly to the blood volume and the time interval in which vessel wall is in contact with the whole blood (14). The silastic cuff was used to lengthen the time interval and the quantity of whole blood around the adventitia. In our study, arterial vasospasm was clearly seen in the vasospasm group comparing to the control group.

a-LA, or thioctic acid, or 1,2-dithiolane-3-pentanoic acid, is a naturally occurring dithiol compound synthesized enzymatically in the mitochondria from octanoic acid. In addition to synthesis, a-LA is also absorbed intact from dietary sources, and it transiently accumulates in many tissues. a-LA is a low molecular weighted substance that crosses the blood brain barrier and it does not have any serious side effects. Although the metabolic role of a-LA has been known for more than 50 years, its effects when given exogenously have become known recently. Several studies have provided evidence that $\mathrm{a}-\mathrm{LA}$ supplementation decreases oxidative stress and restores reduced levels of other antioxidants in vivo. a-LA is an important co-factor in pyruvate dehydrogenase and a-ketoglutarate in the mitochondria. It was found that a-LA inhibits a-ketoglutarate dehydrogenase mediated generation of superoxide and hydrogen peroxide. a-LA has a variety of properties which can interfere with the pathogenesis or progression of neurodegenerative diseases (13).

a-LA is effective in treatment of diabetes, furthermore it had remarkable therapeutic potential in vascular diseases, hypertension and inflammation. Since SAH related cerebral ischemia still has an important role on mortality while prognosis of the surviving patients remains poor, extensive experimental and human studies are currently performed to build up therapeutic strategies for better protection of the cerebral tissues. Panigrafi et al. have shown that the natural thiol antioxidant a-LA is effective in improving survival and protecting the rat against reperfusion injury following cerebral ischemia (17).
The effectiveness of dihydrolipoic acid (DHLA), reduced form of a-LA, in prevention of reperfusion injury has been shown previously (4). a-LA and DHLA are capable of scavenging reactive oxygen species such as hydroxyl radicals, peroxyl radicals, superoxide, hypochlorous acid and peroxynitrite. They prevent singlet oxygen induced DNA damage, exhibit chelating activity, reduce lipid peroxidation and increase intracellular glutathione levels. Therefore $a-L A$ and DHLA have the potency to improve SAH induced oxidative injury.

Considering a recent study of Ersahin et. al. (5), a-LA has a significant neuroprotective effect mediated via enhancing the activity of endogenous antioxidant enzymes, inhibiting neutrophil accumulation and free radical generation. It was reported that $\mathrm{a}$-LA treatment ( $100 \mathrm{mg} / \mathrm{kg} /$ day, po for 2 days) suppressed the high percentage of DNA fragmentation in the brain, while oxidative brain injury was improved. The study has determined a-LA reversed the SAH induced changes, such as increased formation of reactive oxygen radicals, increased DNA fragmentation, increased myeloperoxidase activity, depletion of brain glutathione level, increased $\mathrm{Na}^{+} /$ $\mathrm{K}^{+}$-ATPase activity, to normal significantly on experimental SAH model of rats. In the basilar arteries of the rats treated with a-LA, arterial vasospasm, similar to our histological results with a-LA (100 mg/kg/day, intraperitoneal for 7 days), was decreased providing the integrity of the endothelium.

In the current study, the dose of intraperitoneal $100 \mathrm{mg} /$ $\mathrm{kg} /$ day a-LA decreased the vasospasm and improved the morphological changes related to damage of the vascular structures. These findings could not be seen at the dose of intraperitoneal $20 \mathrm{mg} / \mathrm{kg} /$ day a-LA. Lumen area of the vessel is especially calculated rather than lumen diameter for each groups. In the group, high dose a-LA administered after vasospasm, light microscope analysis showed that all vessels had thin and smooth endothelium, mildly folded internal elastic lamina, concentrically oriented smooth muscle cells resembling the control group. Vascular wall thickness of group IV is significantly lower than group II, and the mean lumen area of group IV is significantly higher than the groups II and III. The results obtained from the study demonstrate high dose of a-LA is efficient in a peripheral artery SAH animal model.

We measured blood glucose levels of the subjects before starting the study and ending for histological analysis because $a-L A$ is currently being used in the treatment of diabetes mellitus. The comparison of first and last blood glucose levels of each groups showed that the amount of decrease in blood glucose levels of the groups 3 and 4 (a-LA administered) was significantly different from that of the groups 1 and 2 (control and vasospasm groups). This finding shows that the effect of the a-LA treatment on blood glucose level should not be ignored. Hypoglycemia was not seen in any group of the subjects during the study.

In addition to the literature, by the present study, the use of low and high doses of intraperitoneal a-LA has lead to support and to improve the recent knowledge on vasospasm. 


\section{CONCLUSION}

a-LA was found to prevent the development of experimental peripheral vasospasm morphometrically. This is the first study to search comprehensively the dose dependent in vivo effects of a-LA on histological and morphological alterations of vasospastic arteries in the experimental rat model. As intraperitoneal administration of $20 \mathrm{mg} / \mathrm{kg}$ and $100 \mathrm{mg} /$ $\mathrm{kg}$ a-LA was studied in vasospasm model, we have found significant difference morphologically related to the dosage. If a-LA dosage is higher, the mean vascular lumen area increases just about the value of the control group.

We believe that the knowledge obtained from our study will shed light to other experimental studies in the determination of effective doses of $a$-LA against vasospasm. Further studies are required for the use of a-LA in cerebral vasospasm (CV) after $\mathrm{SAH}$ in human before definite conclusions can be drawn.

\section{ABBREVIATIONS}

a-LA: alpha lipoic acid, CV: cerebral vasospasm, DHLA: dihydrolipoic acid, SAH: subarachnoid hemorrhage.

\section{REFERENCES}

1. Abdul HM, Butterfield DA: Involvement of PI3K/PKG/ERK1/2 signaling pathways in cortical neurons to trigger protection by co-treatment of acetyl-L-carnitine and alpha-lipoic acid against HNE-mediated oxidative stress and neurotoxicity: Implications for Alzheimer's disease. Free Radic Biol Med 42(3):371-384, 2007

2. Barbosa MD, Arthur AS, Louis RH, Macdonald T, Polin RS, Gazak C, Kassell NF: The novel 5-lipoxygenase inhibitor ABT761 attenuates cerebral vasospasm in a rabbit model of subarachnoid hemorrhage. Neurosurgery 49(5):1205-1212, 2001

3. Bharat S, Cochran BC, Hsu M, Liu J, Ames BN, Andersen JKI: Pre-treatment with R-lipoic acid alleviates the effects of GSH depletion in PC12 cells: Implications for Parkinson's disease therapy. Neurotoxicology 23(4-5): 479-486, 2002

4. Cao X, Phillis JW: The free radical scavenger, alpha-lipoic acid, protects against cerebral ischemia-reperfusion injury in gerbils. Free Radic Res 23(4):365-370, 1995

5. Ersahin M, Toklu HZ, Cetinel S, Yuksel M, Erzik C, Berkman MZ, Yegen BC, Sener G: Alpha lipoic acid alleviates oxidative stress and preserves blood brain permeability in rats with subarachnoid hemorrhage. Neurochem Res 35(3):418-428, 2010

6. Freitas RM: The evaluation of effects of lipoic acid on the lipid peroxidation, nitrite formation and antioxidant enzymes in the hippocampus of rats after pilocarpine-induced seizures. Neurosci Lett 455(2):140-144, 2009
7. Gaetani P, Marzatico F, Lombardi D, Adinolfi D, Rodriguez $Y$, Baena R: Effect of high-dose methylprednisolone and U74006F on eicosanoid synthesis after subarachnoid hemorrhage in rats. Stroke 22(2):215-220, 1991

8. Handa $Y$, Kaneko M, Takeuchi H, Tsuchida A, Kobayashi H, Kubota T: Effect of an antioxidant, ebselen, on development of chronic cerebral vasospasm after subarachnoid hemorrhage in primates. Surg Neurol 53(4):323-329, 2000

9. Horky LL, Pluta RM, Boock RJ, Oldfield EH: Role of ferrous iron chelator 2,2'-dipyridyl in preventing delayed vasospasm in a primate model of subarachnoid hemorrhage. J Neurosurg 88(2):298-303, 1998

10. Jones RE, Moes N, Zwickey $\mathrm{H}$ : Treatment of experimental autoimmune encephalomyelitis with alpha lipoic acid and associative conditioning. Brain Behav Immun 22(4):538-543, 2008

11. Kim DE, Suh YS, Lee MS, Kim KY, Lee JH, Lee HS, Hong KW, Kim CD: Vascular NAD(P)H oxidase triggers delayed cerebral vasospasm after subarachnoid hemorrhage in rats. Stroke 33(11): 2687-2691, 2002

12. Macdonald RL, Weir BK: Cerebral vasospasm and free radicals. Free Radic Biol Med 16(5):633-643, 1994

13. Maczureck A, Hager K, Kenklies M: Lipoic acid as an antiinflammatory and neuroprotective treatment for Alzheimer's disease. Adv Drug Deliv Rev 60(13-14):1463-1470, 2008

14. Mayberg MR, Okada T, Bark DH: Morphologic changes in cerebral arteries after subarachnoid hemorrhage. Neurosurg Clin N Am 1(2):417-432, 1990

15. Mijnhout GS, Alkhalaf A, Kleefstra N, Bilo HJ: Alpha lipoic acid: $A$ new treatment for neuropathic pain in patients with diabetes? Neth J Med 68(4):158-162, 2010

16. Okada T, Harada T, Bark DH, Mayberg MR: A rat femoral artery model for vasospasm. Neurosurgery 27(3):349-356, 1990

17. Panigrahi M, Sadguna $Y$, Shivakumar BR: Alpha lipoic acid protects against re-perfusion injury following cerebral ischemia in rats. Brain Research 717(1-2):184-188, 1996

18. Toklu HZ, Hakan T, Biber N, Solakoglu S, Ogunc AV, Sener G: The protective effect of alpha lipoic acid against traumatic brain injury in rats. Free Radic Res 43(7):658-667, 2009

19. Vollmer DG, Hongo K, Ogawa H, Tsukahara T, Kassell NF: A study of effectiveness of the iron-chelating agent deferoxamine as vasospasm prophylaxis in a rabbit model of subarachnoid hemorrhage. Neurosurgery 28(1):27-32, 1991 